\title{
The Lotus japonicus LjSym4 Gene Is Required for the Successful Symbiotic Infection of Root Epidermal Cells
}

\author{
Paola Bonfante, ${ }^{1}$ Andrea Genre, ${ }^{1}$ Antonella Faccio, ${ }^{1}$ Isabella Martini, ${ }^{1}$ Leif Schauser, ${ }^{2}$ \\ Jens Stougaard, ${ }^{2}$ Judith Webb, ${ }^{3}$ and Martin Parniske ${ }^{4}$ \\ ${ }^{1}$ Dipartimento di Biologia Vegetale dell'Università and CSMT-CNR 10125 Torino, Italy; ${ }^{2}$ Laboratory of Gene \\ Expression, Department of Molecular and Structural Biology, University of Aarhus, Gustav Wieds Vej 10, \\ DK-8000 Aarhus C, Denmark; ${ }^{3}$ Institute of Grassland and Environmental Research, Aberystwyth, \\ Ceredigion, SY23 3EB, U.K.; ' ${ }^{4}$ The Sainsbury Laboratory, John Innes Centre, Colney Lane, Norwich, \\ NR4 7UH, U.K. \\ Accepted 6 June 2000.
}

The role of the Lotus japonicus LjSym4 gene during the symbiotic interaction with Mesorhizobium loti and arbuscular mycorrhizal (AM) fungi was analyzed with two mutant alleles conferring phenotypes of different strength. Ljsym4-1 and Ljsym4-2 mutants do not form nodules with $M$. loti. Normal root hair curling and infection threads are not observed, while a nodC-dependent deformation of root hair tips indicates that nodulation factors are still perceived by Ljsym4 mutants. Fungal infection attempts on the mutants generally abort within the epidermis, but Ljsym4-1 mutants allow rare, successful, infection events, leading to delayed arbuscule formation. On roots of mutants homozygous for the Ljsym4-2 allele, arbuscule formation was never observed upon inoculation with either of the two AM fungi, Glomus intraradices or Gigaspora margarita. The strategy of epidermal penetration by $G$. margarita was identical for Ljsym4-2 mutants and the parental line, with appressoria, hyphae growing between two epidermal cells, penetration of epidermal cells through their anticlinal wall. These observations define a novel, genetically controlled step in AM colonization. Although rhizobia penetrate the tip of root hairs and $A M$ fungi access an entry site near the base of epidermal cells, the LjSym4 gene is necessary for the appropriate response of this cell type to both microsymbionts. We propose that LjSym4 is required for the initiation or coordinated expression of the host plant cell's accommodation program, allowing the passage of both microsymbionts through the epidermis layer.

Additional keywords: cell death, cell wall.

The symbiosis of plant roots with arbuscular mycorrhizal (AM) fungi is widespread both geographically and systematically, probably as a consequence of its presence in the earliest land plants (Remy et al. 1994) and the selective advantage that

Corresponding author: P. Bonfante; Dipartimento di Biologia Vegetale dell'Università and CSMT-CNR, Viale Mattioli 2510125 Torino, Italy; Telephone: 0039011 6502927; Fax: 0039011 6707459; E-mail: p.bonfante@csmt.to.cnr.it plants gain from the symbiosis. The improved uptake of phosphate by AM is of crucial importance in many tropical soils and the impact of AM on ecosystem diversity in moderate climates is significant (Van der Heijden et al. 1998).

Plant mutants unable to form AM are a powerful tool to identify genetically defined steps in the development of the symbiotic interaction. The genetic dissection of AM development has been pioneered by the isolation of pea mutants impaired in AM symbiosis. These mutants were initially identified through their altered root nodule symbiosis with Rhizobium spp. Subsequently, it was found that a subset of the nodulation mutants were also affected in the AM symbiosis (Duc et al. 1989). This finding demonstrated an overlap in the genetic programs for the two diverse symbiotic interactions (Duc et al. 1989; Hirsch and Kapulnik 1998; Albrecht et al. 1999). Unfortunately, the isolation of the affected genes from pea is hampered by its large genome size. We therefore chose to isolate symbiotic mutants from the more amenable model legume Lotus japonicus (Handberg and Stougaard 1992) with the final goal to clone and functionally characterize the responsible genes. A large collection of symbiotic mutants of $L$. japonicus has previously been isolated. Phenotypically, these mutants do not form nodules after inoculation with Mesorhizobium loti, or they form nodules that do not fix nitrogen (Imaizumi-Anraku et al. 1997; Schauser et al. 1998; Szczyglowski et al. 1998; J. Webb, unpublished data). A subset of these mutants was tested by Wegel et al. (1998) for their interaction with the AM fungus Glomus intraradices, and a number of nodulation mutants that were also impaired in the AM symbiosis were identified. Mutants in either of the genes LjSym2, LjSym3, and LjSym4 all displayed a similar phenotype. Fungal infection was blocked at a very early stage of the infection; however, rare successful infection events occurred, leading to the development of structurally intact arbuscules. Wegel et al. (1998) concluded that the LjSym2, LjSym3, and LjSym4 genes played a role during the early stages of the symbiotic infection; however, they were not required for arbuscule formation.

We have now identified a Ljsym4-2 allele in which arbuscule formation was never observed in the interaction with two diverged AM fungi, Glomus spp. and Gigaspora spp. The detailed microscopy of the Ljsym4-2 phenotype, combined with 
immunolabeling of cell wall components, revealed that epidermal cell penetration by G. margarita was associated with localized host epidermal cell death. The rhizobial symbiosis is arrested before infection pockets are formed by root hair curling. This comparative study indicates the LjSym4 gene is required for the epidermal interaction in both symbiotic systems and describes a hitherto unknown active involvement of epidermal cells in the mycorrhizal invasion process.

\section{RESULTS}

\section{EMS1749 harbors a single recessive mutation} affecting both the root nodule and AM symbiosis.

Among the non-nodulation mutants isolated after chemical mutagenesis of L. japonicus (J. Webb, unpublished data), one mutant (EMS1749) was found to be strongly affected in its interaction with Glomus intraradices. The phenotype of this mutant was stable in the $\mathrm{M}_{5}$ generation and the segregation of the mutant phenotype in progeny of the cross to wild-type (WT) L. japonicus ecotype Funakura was $3: 1\left(42: 15 ; \chi^{2}=\right.$ $0.053 ; P>0.05)$. The segregation data indicated that a single, recessive gene was affected in this mutant.

\section{EMS1749 represents a novel allele of the $\mathbf{L j S y m} 4$ locus.}

The LjSym2, LjSym3, and LjSym4 loci were previously shown to be required for both root symbioses (Schauser et al. 1998; Wegel et al. 1998). We therefore performed complementation crosses between EMS1749 and plants carrying mutations in these genes. Progeny from crosses of EMS1749 to either Ljsym2-2 or Ljsym3-1 lines formed root nodules upon
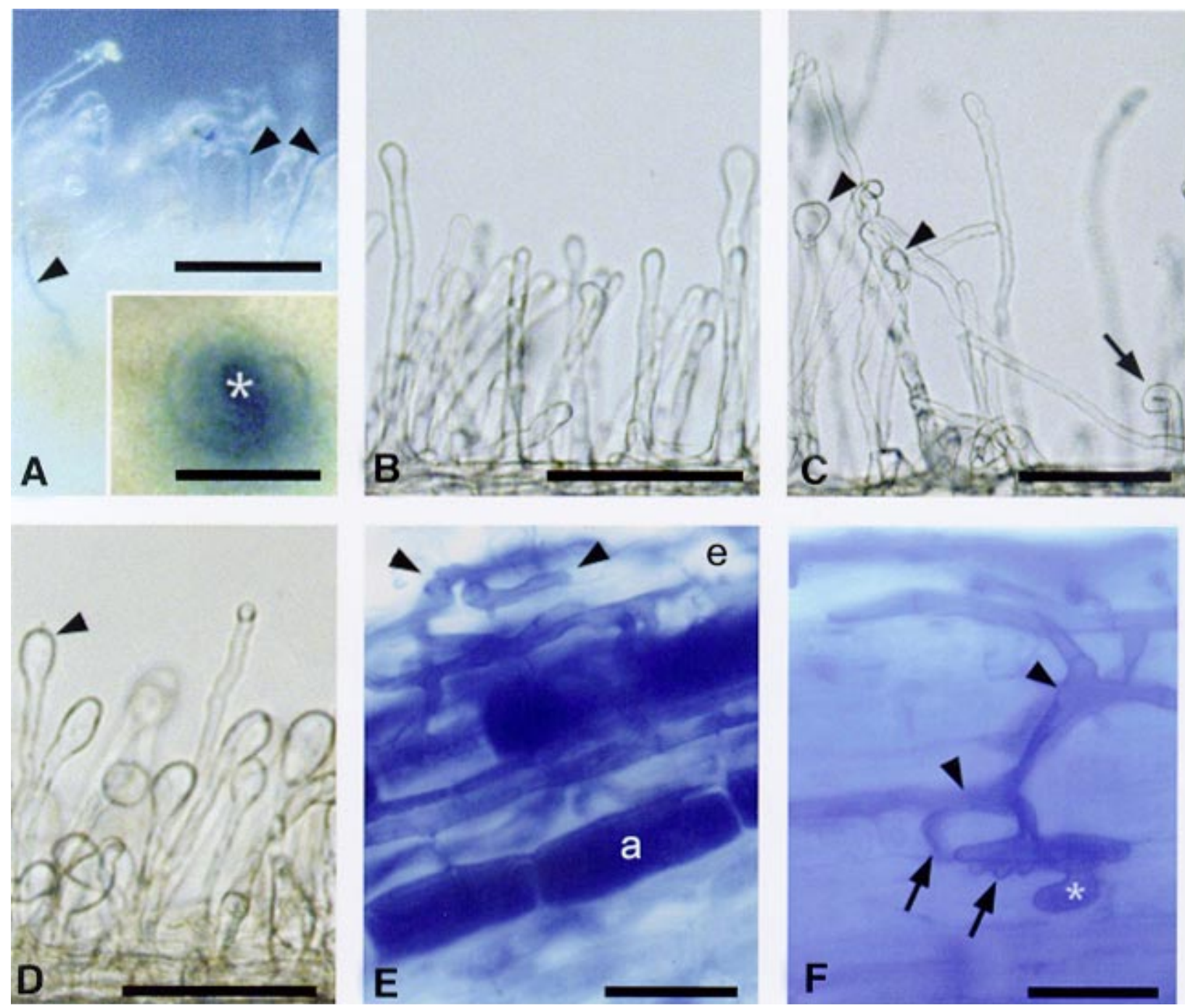

Fig. 1. Mesorhizobium loti and Gigaspora margarita infection process on wild-type (WT) and Ljsym4 mutant plants. A, Infection threads (arrowheads) in WT plant visualized by $\beta$-galactosidase staining of hema-lacz bacteria. Insert: top view of a root hair curling around stained bacteria $(*)$. B, Root hairs on Ljsym4-2 mutants inoculated with the M. loti nodC::Tn5 mutant strain unable to synthesize lipooligo-saccharides. C, Balloon swelling (arrowheads) and curving (arrow) of root hair tips on Ljsym4-1 mutants inoculated with M. loti. D, Balloon swelling (arrowhead) of root hair tips on Ljsym4-2 mutants inoculated with $M$. loti. E, G. margarita colonization on WT roots: hyphae (arrowheads) form appressoria on root surface, penetrate epidermis (e), and reach the cortical cells, where they form the arbuscules (a). F, G. margarita penetration attempt on Ljsym4-2 mutant roots: extraradical hyphae form a branched appressorium (arrowheads) from which various pegs (arrows) penetrate between two adjacent epidermal cells; eventually, one of them passes through the epidermal wall forming a swollen intracellular structure (*). Image obtained by overlapping two photographs taken at different focal planes, the first at the epidermis surface, the second inside the colonized epidermal cell lumen. Bars = A, $2 \mathrm{~mm} ; \mathbf{A}$, insert, $0.5 \mathrm{~mm} ; \mathbf{B}-\mathbf{D}, 1 \mathrm{~mm}$; and $\mathbf{E}$ and $\mathbf{F}, 50 \mu \mathrm{m}$. 
inoculation with $M$. loti. In contrast, progeny of multiple crosses between EMS1749 and LjSym4 consistently failed to form nodules under these conditions. We conclude that EMS1749 harbors a novel mutant allele of the LjSym4 locus, hereafter referred to as Ljsym4-2. The original Ljsym4 allele described by Schauser et al. (1998) is reassigned Ljsym4-1 according to Lotus genetic nomenclature (Stougaard et al. 1999).

\section{The Ljsym4-1 and Ljsym4-2 alleles confer}

\section{different phenotypic strength.}

To compare the early interactions between the two Ljsym 4 mutants and the symbiotic microorganisms, plants were inoculated with M. loti and Glomus intraradices. As both Ljsym4-1 and Ljsym4-2 are non-nodulating mutants, an M. loti strain carrying a hemA-lacZ marker was used to follow the bacterial infection of the root tissue. No infection threads were formed on the two mutant lines (data not shown), while infection threads passing through root hairs into the root cortex were clearly visible on WT control plants (Fig. 1A). On WT plants, lipochitin-oligosaccharide (LCO)-dependent formation of infection pockets by root hair curling precedes infection thread formation (Fig. 1A, insert) (Schauser et al. 1999). Both Ljsym 4 mutants were therefore assayed for root hair curling with WT $M$. loti and a bacterial nodC mutant unable to produce LCO Nod factors. Root hair curling was not observed on either of the mutants. Both Ljsym4-1 and Ljsym4-2 mutants respond to WT M. loti with swelling of the root hair tips (Fig. $1 \mathrm{C}$ and D). Additional deformations like swelling and curving were observed on the Ljsym4 mutants (Fig. 1C). No swelling was observed in response to the nodC bacterial mutant (Fig. 1B). Foci of dividing cortical cells developing into nodule primordia were only observed on the WT plants (data not shown). These results show that the interaction between Ljsym4 mutants and the rhizobial symbionts is arrested before infection thread formation and cortical cell divisions are initiated. However, the initial perception of the LCO signal appears to be functional in the mutants. We conclude that the LjSym4 gene is required for progression of the root hair response into curling and formation of infection pockets.

After 58 days from inoculation of chive nurse plants with Glomus intraradices, the entire root system of 20 plants of each mutant was analyzed. On roots of both mutants, abortive
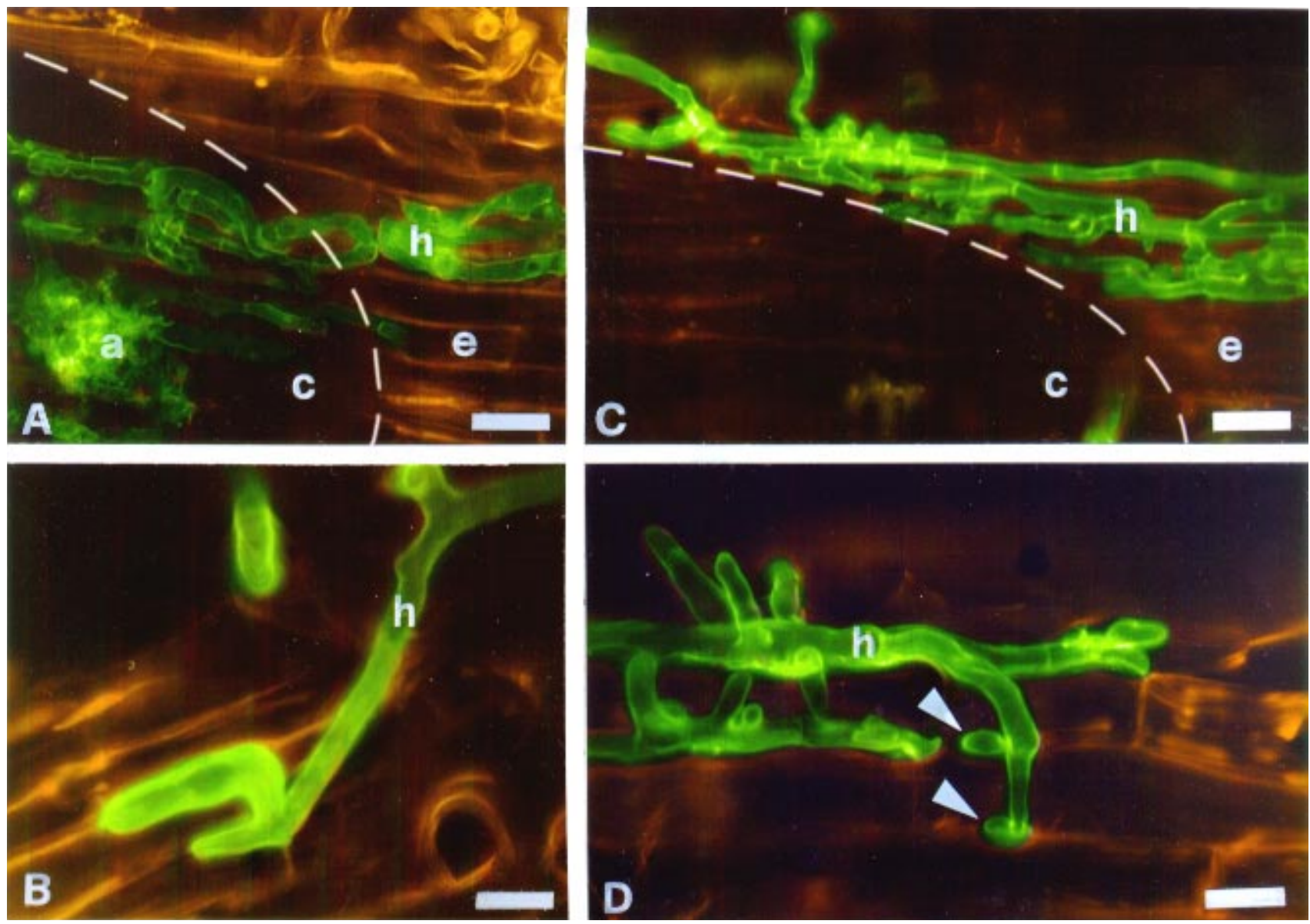

Fig. 2. Development of Gigaspora margarita $\mathbf{A}$ and B, on Lotus japonicus wild-type (WT) line Gifu and $\mathbf{C}$ and $\mathbf{D}$, on Ljsym4-2 mutant, as seen in oblique root sections after staining with fluorescein isothiocyanate (FITC)-conjugated wheat germ agglutinin (WGA) and overlapping of about 20 confocal optical sections, sampled at 1- $\mu \mathrm{m}$ steps. A, Fungal hyphae (h) developing at epidermis surface (e) and branched arbuscules (a) colonizing the cortex (c). A dashed line marks cutting edge separating outside (right part) from inside (left part) of root. B, Detail of an extraradical hypha (h) contacting the epidermis. On the root surface the fungus frequently grows above the grooves formed by two adjacent epidermal cells. C, Abundant fungal hyphae (h) are present on the root epidermis (e) of Ljsym 4-2 mutant, while the cortex (c) is not infected. Dashed line marks cutting edge separating outside (right part) from inside (left part) of the root. D, Detail of an appressorium, with hyphae (h) contacting the epidermal cells. Arrowheads: infection pegs penetrating deeper in the epidermis, between two adjacent cells. Bars = A and C, 40 and $\mathbf{B}$ and $\mathbf{D}, 20 \mu \mathrm{m}$. 
infection events were observed at a high density. On Ljsym4-1 mutants, a small subset of infection attempts was, however, successful. The fungus was able to reach the cortical cell layer of the roots and arbuscules were formed. Lateral spread of the fungus led to the colonization of a long section of the root as the consequence of each single successful infection event. In each of the 20 Ljsym4-1 plants, consistently more than $40 \%$ of the root system was colonized. Despite the very strong infection pressure conferred by the fungus nourished by the chive nurse plants, Glomus intraradices was unable to penetrate the roots of the Ljsym4-2 mutants beyond the epidermis. This result was confirmed in several independent experiments involving plants of various ages grown in different seasons. Arbuscule formation by Glomus intraradices in roots of Ljsym4-2 mutant was never observed in more than 50 plants analyzed. The same results were obtained when $G$. margarita was used as a fungal symbiont on WT and Ljsym4 mutants (Fig. 1E and F).

\section{Light microscopical analysis of fungal development on L. japonicus roots.}

The mycorrhizal invasion process of L. japonicus is poorly described. We therefore subjected the WT line Gifu to a detailed, morphological analysis to characterize its symbiotic development as a basis for comparison with the symbiotic mutant Ljsym4-2. We chose Ljsym4-2 because of the strong and clear-cut phenotype, and, to analyze the early cellular interactions between AM fungi and plant roots, the millipore sandwich method was chosen. This method provides clean and sterile conditions, and restricts fungal growth to two dimensions, leading to a rapid infection. The inoculum can be reproducibly applied because the spore number can be determined. To ease the spore handling involved in the method the large spores of $G$. margarita were used in this study. During 3 weeks of growth in the millipore sandwich, G. margarita produced abundant, extraradical hyphae and auxiliary cells irrespective of the plant genotype (data not shown). Hyphae on the root surface were in loose contact with epidermal cells (Fig. 2A and B), developing appressoria that produced penetrating hyphae (Fig. 2B). On the WT plant, penetration hyphae grew through the epidermal cells and developed intracellular hyphae that, in turn, produced arbuscules (Fig. 2A) in the inner cortical layer, close to the endodermis.

A comparison between the number of penetration points in WT and mutant roots coming from three sets of experiments resulted in two similar patterns: 1.96 and 2.76 penetration points per $\mathrm{cm}$ in WT and mutant plants, respectively, with a very high variability
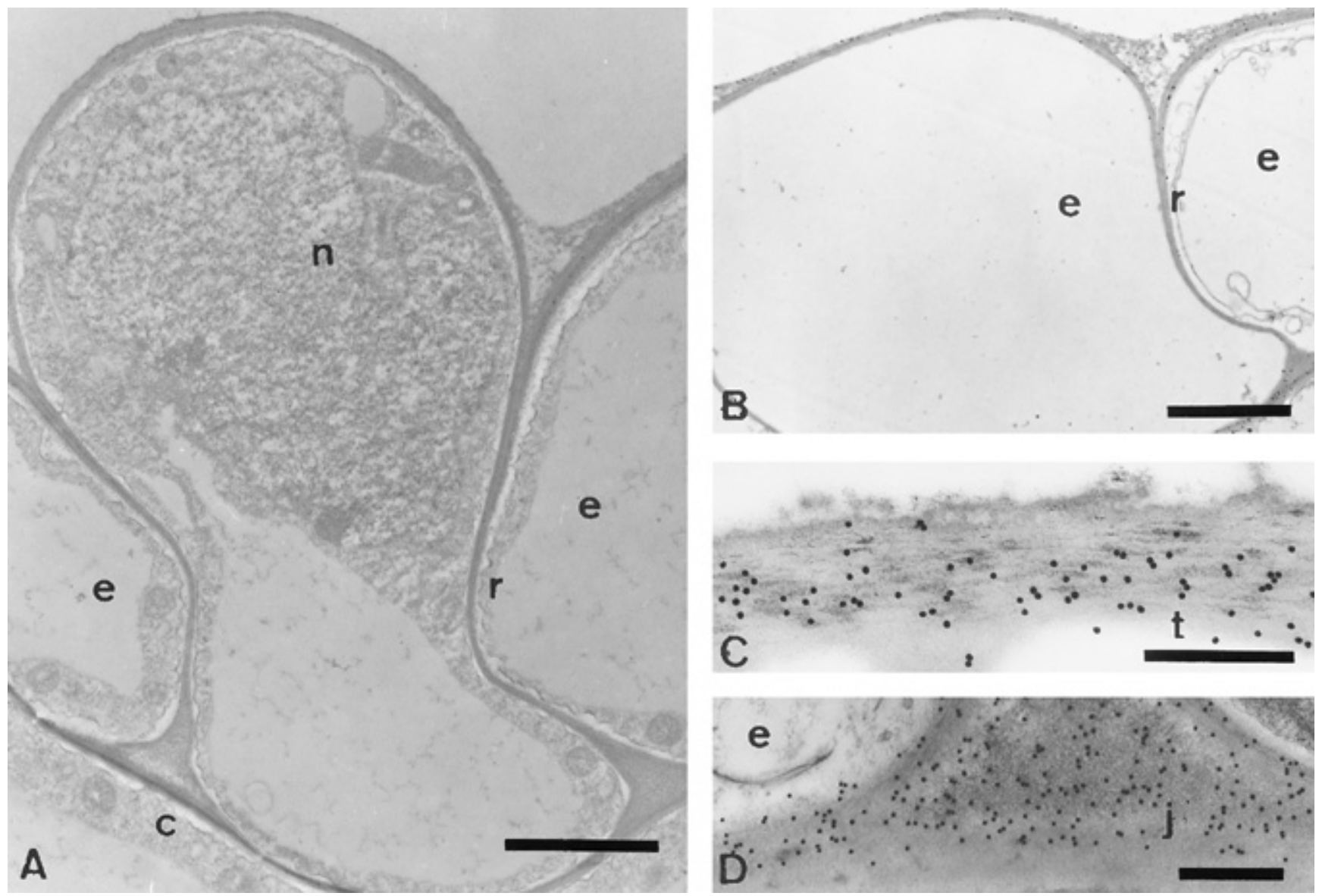

Fig. 3. Ultrastructural features of epidermal cells in Lotus japonicus wild-type (WT) line Gifu in the absence of the fungus. A, Transverse section of a root in the differentiating region. Epidermal cells (e) are tightly joined through their anticlinal walls (r). Central cell, rich in cytoplasm, is developing a root hair $(\mathrm{n}=$ nucleus, $\mathrm{c}=$ cortical cell). B, In a more basal part, epidermal cells (e) are highly vacuolated and tightly joined through their anticlinal walls (r). Immunolabeling with monoclonal antibody (MAb) JIM 5. C, Gold granules are mostly present in inner layer of the tangential wall (t) after immunolabeling with the MAb JIM 7 to detect methyl-esterified pectins. D, Material within triangular junction (j) between epidermal (e) and cortical cells is rich in nonesterified pectin (immunolabeling with the MAb JIM 5). Bars = $\mathbf{A}$ and $\mathbf{B}, 2$ and $\mathbf{C}$ and $\mathbf{D}, 0.5 \mu \mathrm{m}$. 
(standard deviation $=1.73$ and 2.04, respectively). The arbuscule rate (Trouvelot et al. 1986) in WT mycorrhizal roots was $57.5 \%$.

At the root surface of the Ljsym4-2 mutant, abundant hyphae proliferated (Fig. 2C) that, upon contact with root epi- dermal cells, produced appressoria and penetration hyphae, from which hyphal projections (pegs) originated (Fig. 2D). These penetrated epidermal cells, but ceased growing inside this cell layer (Figs. 2D and 5-7). Consistent with the results
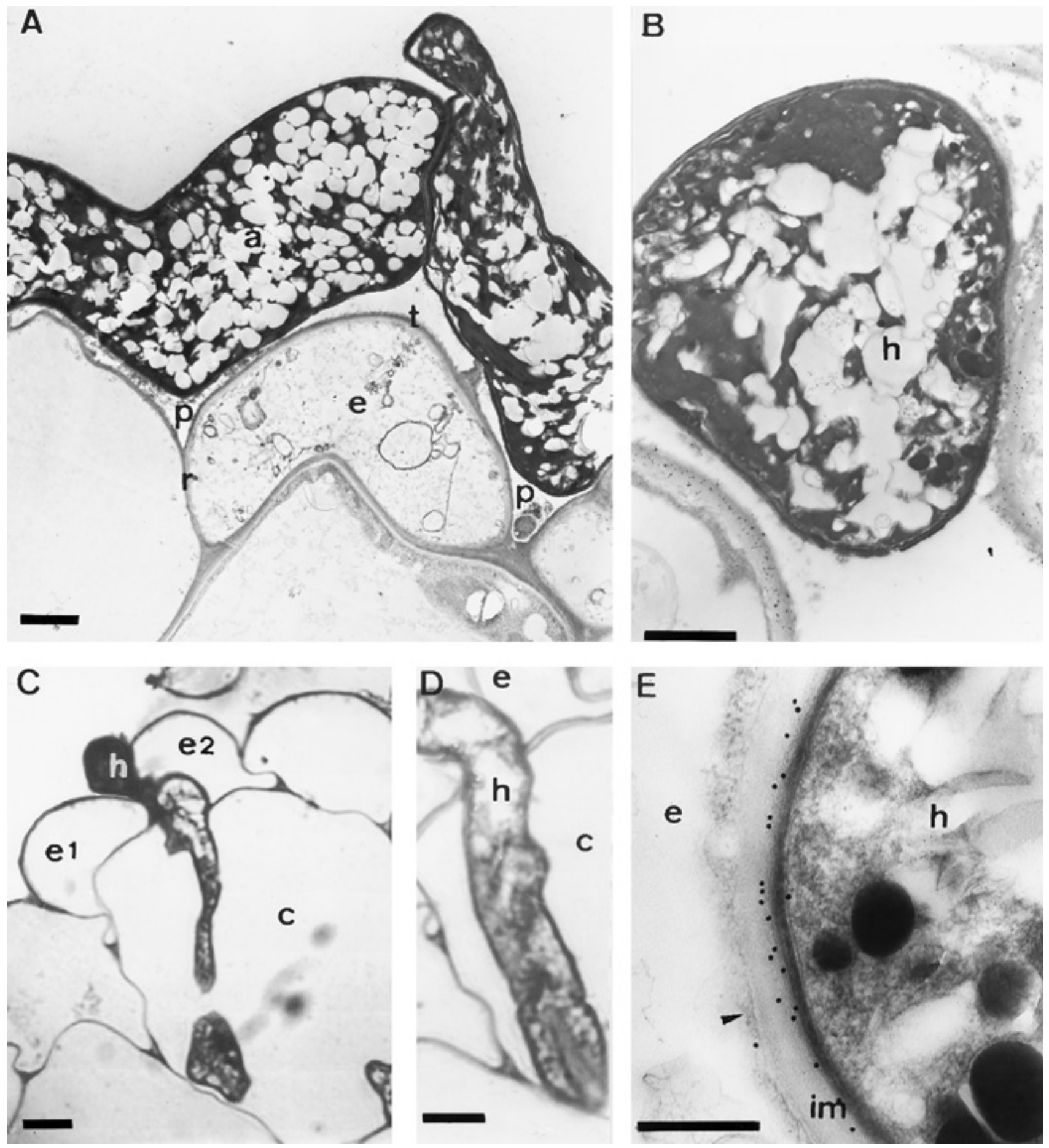

Fig. 4. Light and electronic microscopical features of epidermal cells in Lotus japonicus wild-type (WT) line Gifu in the presence of Gigaspora margarita. A, An appressorium (a) contacts outer tangential wall (t) of an epidermal cell (e). Appressorium produces two penetrating hyphae (p) that grow between anticlinal epidermal cell walls (r), causing their separation. B, A large channel separates two epidermal cells in the vicinity of fungal hypha (h). C, Light micrograph showing a hypha (h) that develops intercellularly between two epidermal cells (e1 and e2), penetrates one (e2), and then moves to the underlying cortical cell (c). D, Detail of a serial section showing the same hypha (h) passing from the epidermal (e) to the cortical (c) cell. E, Ultrastructural aspect of an intracellular hypha colonizing an epidermal cell. Immunolabeling with the monoclonal antibody (MAb) JIM 5. Gold granules are seen on the interface material (im) occurring between the hypha (h) and the invaginated membrane (arrowhead) of an epidermal cell (e). Bars = A, 2; B, $0.5 ; \mathbf{C}, 10 ; \mathbf{D}, 5$; and $\mathbf{E}, 0.3 \mu \mathrm{m}$. 

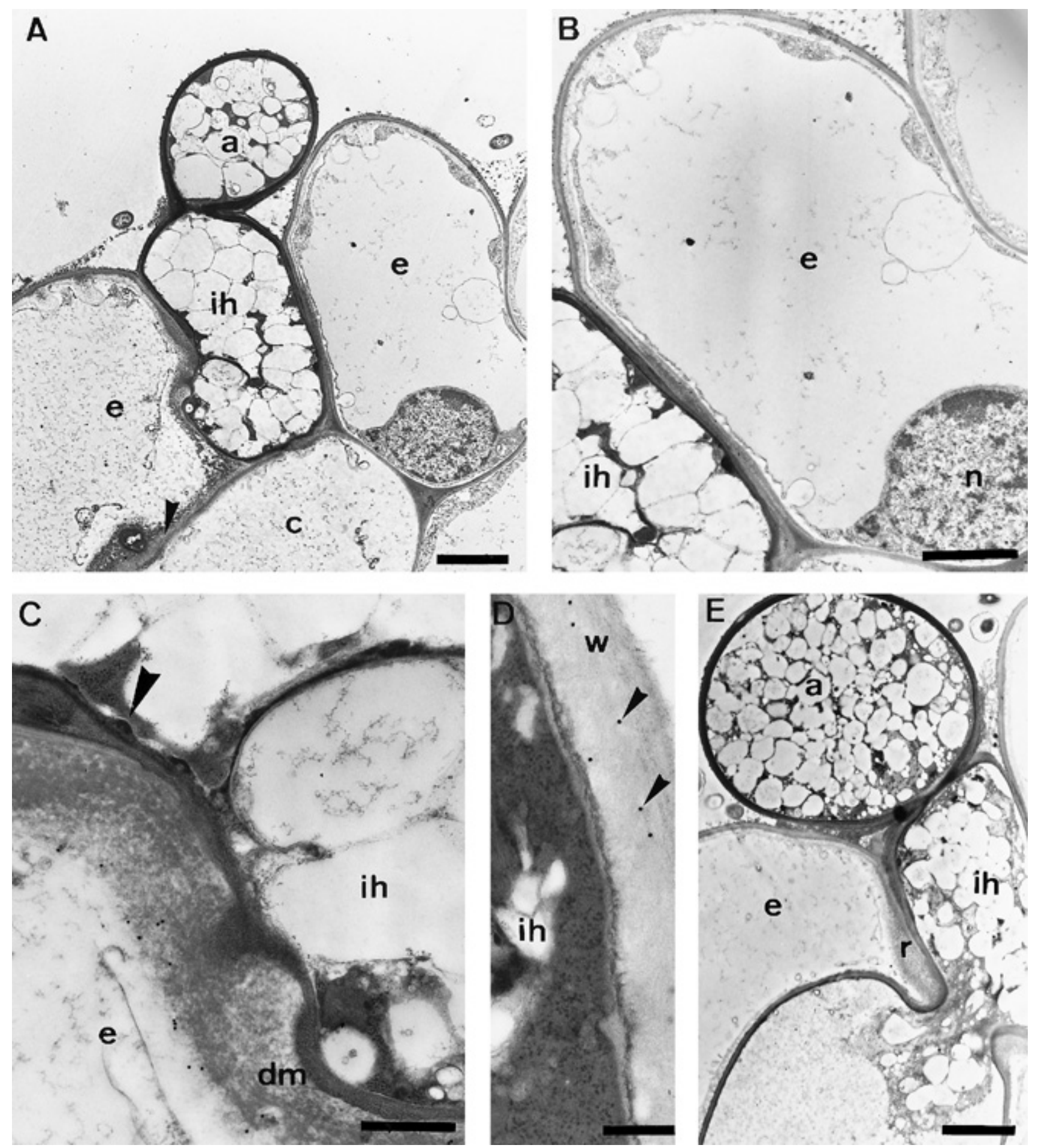

Fig. 5. Ultrastructural features of contacts between epidermal cells in Lotus japonicus Ljsym4-2 mutant and Gigaspora margarita. A, An appressorium (a) is positioned above two epidermal cells. An intercellular hypha (ih) penetrated between adjacent epidermal cells (e). A thickening (arrowhead) is present in the periclinal wall of the underlying cortical cell (c). B, Magnification of $\mathbf{A}$ showing cell wall structure of an epidermal cell (e) in close contact with a fungal hypha (ih) but not subject to fungal colonization attempts. It shows regular organelles. Central vacuole is electron transparent. $\mathrm{n}=$ Nucleus. C, Magnification of A showing contact between protrusion of intercellular hypha (ih) and anticlinal wall of an epidermal cell (e). Electron-dense material (dm), partly reactive to monoclonal antibody (MAb) JIM 5, surrounds the fungal peg. Wall of fungal peg shows electron-dense granules (arrowhead). D, Contact between plant wall (w) and fungus (ih) after treatment with MAb against $\beta-1,3$ glucans (arrowheads). E, Appressorium (a) produces a penetrating intercellular hypha (ih), which crosses anticlinal wall (r) of an epidermal cell (e). Penetrating hypha is abnormally swollen and exhibits a highly degenerated cytoplasm. Most of the fungal cell wall is not lined with cytoplasm. Host cytoplasm, organelles, and membranes are not detectable, suggesting plant cell death. Bars = A, 3; B and E, 2; $\mathbf{C}, 0.5$; and $\mathbf{D}, 0.3 \mu \mathrm{m}$. 
obtained with Glomus intraradices, cortical cells were never found to be colonized upon inoculation with $G$. margarita (Fig. 2C).

\section{Epidermal cell wall architecture of $\boldsymbol{L}$. japonicus roots.}

Since epidermal cells seem to play a role in the response of L. japonicus to symbiotic microorganisms, their ultrastructural morphology in WT and mutant plants was compared. The root surface of L. japonicus WT consisted of tightly joined, epidermal cells, often with root hairs (Fig. 3A). The morphology of epidermal cells varied according to their position. In the apical region, living cells had peripheral cytoplasm and a central vacuole, while highly vacuolated cells were present in the older, proximal regions (Fig. 3B). The thick outer wall of epidermal cells consisted of two layers, the outer one becoming looser mostly at the junction between two epidermal cells (Fig. 3A and B). The anticlinal walls were thinner by comparison (Fig. 3A and B). Immunofluorescence (data not shown) and immunogold experiments were performed to determine some cell wall components with JIM 5 and JIM 7 monoclonal antibodies (Mabs), which detect nonesterified and methylesterified pectins, respectively. They revealed a differential presence of these components in the epidermal walls (Fig. 3B-D). Nonesterified pectins were loosely present at the junction be- tween epidermal cells and on the tangential wall (Fig. 3B) and in the intercellular material occurring between epidermal and cortical cells (Fig. 3D). Gold granules indicating the presence of esterified pectins were less abundant and were mostly located on the outer wall of the epidermal cells (Fig. 3C). $\beta-1,3$ glucans were not detected (data not shown). Control sections did not show any relevant labeling.

The appearance of the epidermal cells and their wall architecture was indistinguishable between $L$. japonicus WT and the Ljsym4-2 mutants. Similarly, no epidermal cell wall alterations were observed when extraradical hyphae developed around WT or mutant plants (data not shown).

\section{Development of $G$. margarita on $L$. japonicus roots.}

On the surface of inoculated roots, appressoria were identified as swollen fungal structures, 8 to $16 \mu \mathrm{m}$ in diameter, from which penetration hyphae were produced (Fig. 4A). The underlying epidermal cells, which were of comparable diameter to the appressorium, were often deformed. The appressorium cell wall was thick, electron dense, and rich in granules (Fig. 4A and B) already identified as melanin granules (Grippiolo and Bonfante 1984).

The penetrating hyphae separated two adjacent, epidermal cells, producing a deep furrow. The cell wall material joining
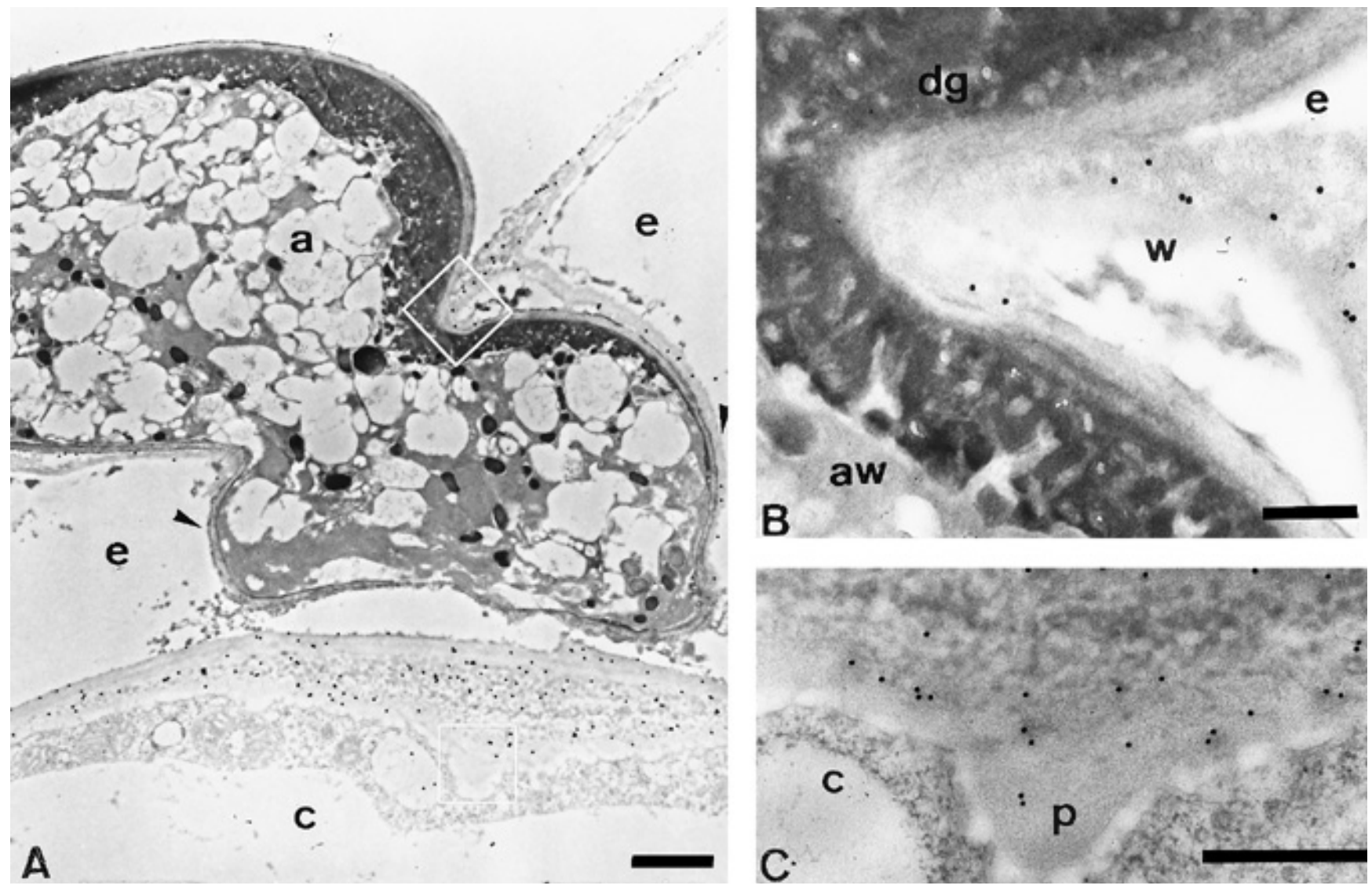

Fig. 6. Ultrastructural features of colonization events of epidermal cells in Lotus japonicus Ljsym4-2 mutant by Gigaspora margarita. A, An appressorium (a) produces a swollen penetrating hypha that causes deformation of epidermal cells (e), anticlinal walls of which are broken $(\mathrm{arrowhead}) . \mathrm{c}=\mathrm{Cor}-$ tical cells. B, Magnification of upper lined area of A. Appressorium wall (aw) is strongly pigmented, due to a number of granules (dg) closely packed in a thick, electron-dense layer. Host wall material (w) of epidermal cell (e) labeled by monoclonal antibody (MAb) JIM 5 surround s the fungal peg. Wall of fungal peg shows electron-dense granules (arrowhead). D, Contact between plant wall (w) and fungus (ih) after JIM 5 to detect nonesterified pectins. C, Magnification of lower lined area of A. Immunolabeling with MAb JIM 5. Labeling is seen in the thickening occurring in the underlying cortical cell wall (c). Thickening projections (p) are also labeled. Bars = A and B, 1; and $\mathbf{C}, 0.5 \mu \mathrm{m}$. 
the epidermal cells was ruptured and the anticlinal cell walls connecting the adjacent epidermal cells were eventually fully separated (Fig. 4A and B). The MAb that detects $\beta-1,3$ glucans led to the deposition of a few gold granules at the epidermal surface (data not shown).

The separation of epidermal cells by the penetration hypha was followed by the production of a short branch that entered one of the two adjacent epidermal cells (Fig. 4C). The penetration site was preferentially located along the thin, anticlinal wall and at the base of the epidermal cell. From this position, the hypha passed through the epidermal cell into the underlying cortical cell (Fig. 4D), where it produced a long, nonbranched hypha that reached the inner cortical cells close to the endodermis. Here, it branched and produced terminal arbuscules.

The intracellular growth of the fungus was always associated with an invagination of the host membrane, as widely reported for AMs (Bonfante and Perotto 1995; Bonfante, in press). Pectins were present in the material laid down by the host at the interface occurring between the perifungal membrane and the large hyphae colonizing the epidermal cells (Fig. 4E). $\beta-1,3$ glucans were limited to plasmodesmata (data not shown).

\section{Development of $G$. margarita on Ljsym4 mutant roots.}

On roots of the Ljsym4-2 mutant, G. margarita produced electron-dense appressoria, which originated hyphae, often successful in penetrating the L. japonicus walls (Figs. 5 and 6). Penetration hypha separated the adjoining anticlinal walls of two epidermal cells, and produced one or two infection pegs, located at the base of the epidermal cell (Fig. 5A). As a result, the membrane of the epidermal cell involved in the event disintegrated; electron-dense material, partly reactive to JIM 5, was accumulated around the fungal peg, and the vacuole appeared rich in granular contents (Fig. 5A). The wall of
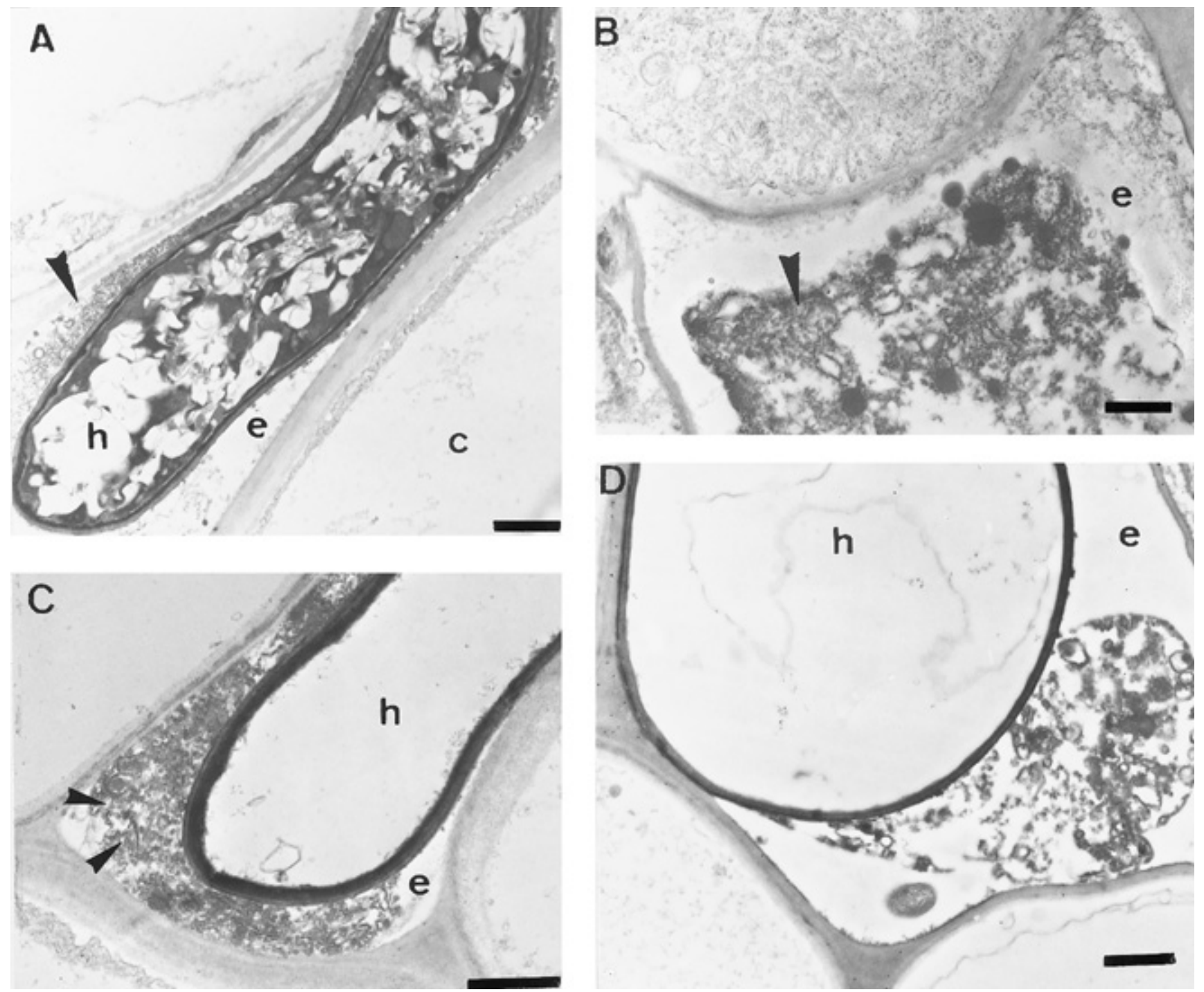

Fig. 7. Ultrastructural features of colonization events of epidermal cells in Lotus japonicus Ljsym4-2 mutant by Gigaspora margarita. A, A swollen hypha (h) - seen in a longitudinal section-fills up cell lumen. Electron-dense material (arrowhead) is present around hypha $(\mathrm{e}=$ epidermal cell, $\mathrm{c}=\mathrm{corti}-$ cal cell). B, Detail of infected epidermal cell (e), which exhibits convolution of membrane system (arrowhead), and electron-dense granules. C, Masses of electron-dense material (arrowheads) are seen inside a dead epidermal cell (e). $\beta-1,3$ glucans are not detected on host cell wall after labeling with $\beta$ 1,3 glucans monoclonal antibody (MAb). Fungal hypha (h) is empty. D, A large empty hypha (h) is present inside an epidermal cell (e) that contains degraded cytoplasm, suggesting plant cell death. Bars = $\mathbf{A}$ and $\mathbf{C}, 1$; and $\mathbf{B}$ and $\mathbf{D}, 0.5 \mu \mathrm{m}$. 
the fungal peg was layered with embedded, electron-dense granules (Fig. 5C). The morphology of the neighboring epidermal cell, which was not involved in the colonization attempt, did not reveal any changes (Fig. 5B). When the MAb was used to localize $\beta-1,3$ glucans, a few gold granules were seen at the contact between the penetration hypha and the wall of the epidermal cell (Fig. 5D). The position of these was similar to the situation in WT samples (data not shown). The wall between epidermal and cortical cells below the position of the fungus appeared thickened when compared with the other walls of the same cortical cell (Fig. 5A).

Another aspect of fungal penetration is shown in Figure 5E. The crossing of the anticlinal wall of the epidermal cell is first associated with a constriction of the penetration hyphae and then with its swelling (Fig. 5E).

In some samples, the swollen, intracellular hyphae deformed the epidermal cells, the anticlinal walls of which appeared broken (Fig. 6A) and reactive to JIM 5 (Fig. 6B). The appressorium wall was strongly pigmented, due to a number of granules closely packed in a thick, electron-dense layer (Figs. $6 \mathrm{~B})$. Only membrane and cytoplasm remnants could be seen around the hypha (Fig. 6B). The underlying cortical cell exhibited a localized wall thickening in the vicinity of the infection event (Fig. 6A and C). It showed a spongy texture where electron transparent areas were mixed with electron-dense ones. The wall thickening was irregularly labeled by JIM 5, while it was not labeled by the other two MAbs used to locate esterified pectins and $\beta-1,3$ glucans.

As a consequence of the swollen hyphae that filled up the cell lumen (Figs. 6A and 7A), the infected epidermal cell exhibited convolution of the membrane system-which became progressively osmiophilic - and electron-dense granules (Fig. 7A and B). Lastly, an accumulation of electron-dense material characterized the epidermal cell (Fig. 7C), while $\beta-1,3$ glucans were not detected within its wall (Fig. 7C and D). All of the epidermal colonized cells inspected by electron microscopy appeared morphologically dead.

The abortion of infection attempts was also associated with a localized death of fungal hyphae. While extraradical hyphae appeared structurally intact (Figs. 5E and 6A), they were in continuum with intracellular parts, which suffered from a degenerated cytoplasm (Figs. 5E and 7C). Eventually, empty hyphae were seen inside empty epidermal cells (Fig. 7D).

\section{DISCUSSION}

\section{The root epidermis: An active checkpoint in symbiotic infection.}

Root epidermal cells and their protrusions, the root hairs, form the first physical barrier encountered by symbiotic microorganisms on their way to the root cortex. On L. japonicus roots, $M$. loti reaches the root cortex via infection threads that pass through root hairs, while AM fungi gain access to a cortical cell by separating two adjacent epidermal cells. Hyphae, however, do not proceed directly into the cortex; instead, a detour is taken that involves the infection of an epidermal cell. This detour suggests that epidermal cell infection is a prerequisite for initiating the successful colonization of the cortex. A similar penetration mechanism has been described in leek (Garriock et al. 1989), maize (Bonfante, in press), and a Colchicum sp. (Gallaud 1905, quoted in Smith and Smith 1997).
Not only these morphological observations, but also our genetic data reveal the critical role of the root epidermis as a checkpoint for mycorrhizal invasion. The mycorrhizal phenotype of Ljsym4-1 mutants suggests a cell type-specific requirement of LjSym4. The Ljsym4-1 allele exerts a strong effect within epidermal cells, where the majority of infection attempts are aborted. However, some gene function appears to be retained, allowing a few invasions to proceed into the root cortex. In older Ljsym4-1 roots, fungal colonization and arbuscule formation reach levels comparable to those in the WT, indicating that the limiting step in this interaction is the passage through the epidermis.

\section{LjSym4 is required for the successful infection of epidermal cells by symbiotic microorganisms.}

LjSym4 is essential for a step common to both root symbioses. Mutant analysis suggests that LjSym4 is involved in a process occurring in epidermal cells and essential for infection by both symbiotic microorganisms. Root hairs of L. japonicus respond to $M$. loti with curling and formation of infection pockets. The root cortex is reached through the infection thread formed by the plant host (Szczyglowski et al. 1998; Schauser et al. 1999). AM fungi also rely on the formation of an infection structure by the plant (Garriock et al. 1989). During all stages of symbiotic bacterial and fungal infection, intracellular microbes are surrounded by a perimicrobial membrane. In the space between this host-derived membrane and the invading microorganism, so-called interface material is deposited that is, at least in part, of plant origin. The plant-fungus interface is morphologically and immunologically related to the plantbacterium interface formed during the Rhizobium symbiosis (Perotto et al. 1994; Bonfante and Perotto 1995; Harrison 1999a). Both the synthesis of the perimicrobial membrane and the deposition of interface material presumably require a specific set of metabolic activities of the host cell, which are part of the general accommodation program of the host required to support microbial development within the plant root (Parniske 2000). Our analyses of Ljsym4 mutants show that infection threads are not formed upon $M$. loti contact and the perifungal membrane does not develop around $G$. margarita, while a fully developed interface compartment with the expected pectin components was identified in the parental line. These observations suggest that $\mathrm{LjSym} 4$ is required for this accommodation process within the epidermis. According to this hypothesis, insufficient structural support is provided in Ljsym4 mutant epidermal cells and consequently fungal infection attempts are aborted. Because of the lack of structural containment by the plant, the hyphae invading the mutant epidermal cells increase abnormally in diameter. In this scenario, the arrested rhizobial interaction as well as the host and fungal cell death at the site of infection would be consequences of the incompetence of the host to support normal symbiotic development. On the Ljsym4 mutants, the rhizobial-triggered nodulation process was arrested prior to infection and only swelling and deformation of root hairs were observed. In Vicia sativa, root hair tip swelling was shown to be the first visible response to LCO addition and following this swelling the $V$. sativa root hairs initiate an asymmetric tip growth leading to root hair curling (Heidstra et al. 1994). Our data are consistent with the idea that a similar chain of events occurs in root hairs of L. japonicus. However, curling of root hairs to form the in- 
fection pockets and initiation of infection thread formation was not observed on the mutants. Therefore, the LjSym4 gene appears to be necessary for the developmental process setting up the invasion structures after the initial LCO perception. Epidermal cells of Ljsym4 mutants are invaded by AM fungi but not by $M$. loti. This difference might be explained by the different forces that bacteria and fungi, thanks to their appressoria, are able to impose on plant cell walls. Due to a combination of physical forces and enzymatic activities (Bonfante and Perotto 1995), AM fungi are able to force entry into the mutant epidermal cell, whereas the smaller rhizobia cannot enter without the active contribution of the plant cell (Parniske 2000).

\section{Is LjSym4 epidermal cell death caused by a defense response?}

Epidermal cell death upon infection with AM fungi could be the consequence of a hypersensitive response (HR), which is a commonly observed response of resistant plants to attack by pathogens (Heath 1997). A large number of so-called disease-lesion-mimic mutants of several plant species have been described (Dangl et al. 1996). These "paranoid plants" (Jones 1994) inappropriately respond with cell death to various biotic and abiotic stimuli. If Ljsym 4 mutants responded to signals of both microsymbionts inappropriately with cell death, the abolition of infection of both microsymbionts would be a plausible consequence. However, our morphological observations did not reveal any evidence of defense-related mechanisms specifically elicited by the symbionts in Ljsym4 mutant cells. First, no cell death was observed when Ljsym4 roots were inoculated with $M$. loti, indicating that the lack of infection thread formation was not a consequence of cell death. Second, $\beta-1,3$ glucans indicative of callose-observed at the contact between AM fungi and mutant peas (Gollotte et al. 1993) — were not revealed in the Ljsym4-2 mutant upon epidermal cell entry by $G$. margarita. Detectable amounts were, however, present adjacent to superficial contacts of hyphae with roots of Ljsym4-2 or the parental line (data not shown), probably another manifestation of the weak and transient induction of defense responses widely reported for AMs (Gianinazzi-Pearson 1996; Barker et al. 1998b). We therefore have no evidence in favor of the idea that mutations in LjSym4 give rise to a diseaselesion-mimic phenotype.

\section{The phenotype of Ljsym4 mutants differs}

from previously described symbiotic plant mutants.

AM fungi form appressoria prior to root penetration (Giovannetti et al. 1996; Harrison 1999b). G. margarita produces appressoria on isolated epidermal cell walls (Nagahashi and Douds 1997), suggesting that the epidermal cell wall itself provides the signals that trigger appressoria formation. Our results show that epidermal cell wall architecture is similar in both WT and Ljsym4-2 mutants. The localization of the analyzed cell wall components performed by the use of different MAbs is unchanged. Consistently, appressoria were produced on the surface of Ljsym4 mutant roots, demonstrating that plant signals required for appressoria formation are provided. All plant mutants described so far that are affected in the interaction with AM fungi trigger appressorium formation (Bradbury et al. 1993; Duc et al. 1989; Sagan et al. 1995; Shirtliffe and Vessey 1996; Wegel et al. 1998, Barker et al. 1998a).
Four pea loci (PsSym8, PsSym9, PsSym19, and PsSym30) have been identified, mutations of which affect the early stages of both root symbioses (Albrecht et al. 1998; Balaji et al. 1994; Borisov et al. 1994; Schneider et al. 1999). AM fungi form appressoria on the corresponding mutant root surfaces, but subsequent penetration of plant root cells is blocked (Balaji et al. 1994; Duc et al. 1989; Gollotte et al. 1993; GianinazziPearson 1996). Whereas root hairs of Pssym9 and Pssym19 mutants respond with curling, root hairs of Pssym 8 do not deform upon inoculation with Rhizobium spp. (Markwei and LaRue 1992; Postma et al. 1988). In the interaction with rhizobia, the root hair response of our Ljsym4 mutants is therefore intermediate between that of the Pisum mutants, and also their AM phenotypes differ. Ljsym4 mutants appear to be impaired at a later step of the infection process, because epidermal cell penetration by AM fungi still occurs. An even later step in AM development is defective in the RisNod24 mutant of $P$. sativum cv. Finale, which allows invasion of cortical cells, but only supports the formation of stumpy fungal branches instead of normal arbuscules (Gianinazzi-Pearson 1996).

Our observations define a novel, genetically controlled step in the fungal invasion process, not covered by the described phenotypes of pea. Our observations also demonstrate that plant responses to the fungus are cell layer dependent.

\section{MATERIALS AND METHODS}

\section{Mutagenesis of $L$. japonicus.}

Several symbiotic mutants of L. japonicus B-129-S9 Gifu (Handberg and Stougaard 1992) were generated in a chemical mutagenesis program that will be described in full elsewhere (J. Webb, personal communication). EMS 1749 (LjSym4-2) is a symbiotic mutant, failing to form nodules after inoculation with $M$. loti and to support colonization by AM fungi. To avoid confusion with symbiotic (Sym) genes identified in other plants, the two letter prefix $L j$ for Lotus japonicus is now consistently applied (Stougaard et al. 1999). Ljsym4-1 mutant 282-227 was isolated from a tagging population, originated from transformation by an Agrobacterium sp. (Schauser et al. 1998).

\section{Plant culture and $M$. loti interaction.}

The visualization of infection threads by $\beta$-galactosidase staining for hemAlacZ carrying $M$. loti bacteria in root explants was as described by Boivin et al. (1990) and Schauser et al. (1999). To detect foci of cell division, roots were examined by fluorescence microscopy (Schauser et al. 1999). The root hair curling and deformation assay was as follows: scarified and sterilized seeds were imbibed for 2 days on wet filter paper. They were then transferred to plates containing $2 \%$ Agar Noble 1/4 B\&D medium, and grown for 2 days before adding WT $M$. loti or an nodC::Tn5 M. loti mutant strain (Handberg and Stougaard 1992). Roots were cut off 3 days later and placed on a microscopy slide with a drop of a $0.001 \%$ Tween 20 solution. The roots were examined by brightfield microscopy.

\section{Plant cultures and fungal strains.}

L. japonicus seeds (Gifu, WT, and mutants, Ljsym4-21 and Ljsym4-2) were scarified and surface-sterilized for $5 \mathrm{~min}$ in concentrated sulfuric acid, washed three times with sterile wa- 
ter, and germinated on water agar in petri dishes. Ten-day-old seedlings were inoculated with Glomus intraradices Schenk and Smith (a single-spore descendant line obtained from D. Redecker, Philipps-University, Marburg, Germany) with chive nurse plants, grown and analyzed as described by Wegel et al. (1998).

As an alternative method for cellular analysis, about 10 days after germination, seedlings were inoculated with Gigaspora margarita Becker and Hall (strain deposited in the Bank of European Glomales as BEG 34) by the millipore sandwich method (Giovannetti et al. 1993). Three seedlings were placed between two membranes (pore diameter $0.45 \mu \mathrm{m}$; Sartorius, Goettingen, Germany), either with 10 to 15 fungal spores or without any spores. Seedlings with the membranes attached were planted in sterile acid-washed quartz sand in Magenta GA-7 vessels (Sigma Aldrich, Milan, Italy) and grown in a climatic chamber at $20^{\circ} \mathrm{C}, 60 \%$ humidity, with $14 \mathrm{~h}$ of light per day. After 3 weeks, samples from roots were cut after observation under a stereo microscope. Some segments were stained with $0.1 \%$ cotton blue in lactic acid and the infection was quantified as described by Trouvelot et al. (1986); other fragments were processed for immunofluorescence and electron microscopy. Root segments from six independent experiments and a total of 30 sandwich cultures were analyzed.

\section{Staining of nuclei and fungal structures.}

Root segments were fixed for $1 \mathrm{~h}$ at room temperature with $3 \%$ paraformaldehyde in PEM buffer (50 mM PIPES [piperazine- $N$ - $N$ '-bis(2-ethanesulfonic acid)]- $\mathrm{Na}_{2}, 5 \mathrm{mM}$ EGTA, $5 \mathrm{mM} \mathrm{MgSO}_{4}, \mathrm{pH} 7$ ). Samples were subsequently washed with PEM, embedded in $10 \%$ agarose, and cut into $50-\mu \mathrm{m}$ sections with a vibratome. Nuclei were stained by incubating the sections for $10 \mathrm{~min}$ with $50 \mu \mathrm{g}$ of propidium iodide per $\mathrm{ml}$ in $0.02 \mathrm{M}$ phosphate buffer (PB), $\mathrm{pH} 7$. Fungal structures were stained by treating the sections for 10 min with $\mathrm{NaHClO}$ $1.5 \%$ in $\mathrm{PB}(\mathrm{pH} 7,0.02 \mathrm{M}$ ) and subsequent incubation for $1 \mathrm{~h}$ in $\mathrm{PB}(\mathrm{pH} 7,0.02 \mathrm{M})$ containing fluorescein isothiocyanate (FITC)-conjugated wheat germ agglutinin (WGA) $10 \mu \mathrm{g} / \mathrm{ml}$.

Samples were observed with a Nikon Optiphot-2 microscope equipped with a Bio-Rad View Scan DVC-250 confocal system, under an excitation light of $488 \mathrm{~nm}$ and $514 \mathrm{~nm}$. Images collected with a Hamamatsu C5985 Chilled CCD Camera were processed on an Apple computer with Adobe Photoshop and NIH Image software.

\section{Electron microscopy.}

Root segments from six independent experiments were fixed in $2.5 \%$ (vol/vol) glutaraldehyde in $10 \mathrm{mM}$ Na-phosphate buffer ( $\mathrm{pH} 7.2$ ) for $2 \mathrm{~h}$ at $4^{\circ} \mathrm{C}$. After being rinsed with the same buffer, samples were postfixed in $1 \%$ (wt/vol) $\mathrm{OsO}_{4}$ in double-distilled $\mathrm{H}_{2} \mathrm{O}$ for $1 \mathrm{~h}$, washed three times with doubledistilled water, and dehydrated in an ethanol series $(30,50,70$, 90, and $100 \%$; 10 min each step) at room temperature. The root segments were infiltrated in $2: 1$ ( $\mathrm{vol} / \mathrm{vol})$ ethanol/LR White resin (Polysciences, Warrington, PA, U.S.A.) for $1 \mathrm{~h}$, 1:2 (vol/vol) ethanol/LR White for $2 \mathrm{~h}$, and $100 \%$ LR White overnight at $4{ }^{\circ} \mathrm{C}$ according to Moore et al. (1991). Semithin sections $(1 \mu \mathrm{m})$ were cut from 15 to 20 root-embedded samples for each genotype (WT and mutant) in the presence and in the absence of the fungus. Sections were stained with $1 \%$ toluidine blue for morphological observations.

\section{Immunocytochemistry.}

Six independent immunogold experiments were performed for each treatment. For each of them, five LR White, embedded samples were selected. For the location of nonesterified and methylesterified pectins, rat MAbs JIM5 and JIM7 (Knox et al. 1990) were used, respectively, while for detection of $\beta$ 1,3 glucans, a mouse MAb was used (Biosupplies Australia, Parkville). Immunogold labeling was performed on thin sections as described by Balestrini et al. (1996). About 50 thin sections from each selected, embedded sample were handled as floating sections. The sections were incubated for $15 \mathrm{~min}$ in normal goat serum diluted 1:30 in $0.05 \mathrm{M}$ 2-amino-2 (hydroxymethyl)-1-3 propanediol (Tris)-HCl buffer with 500 $\mathrm{mM} \mathrm{NaCl}$ (TBS, $\mathrm{pH} 7.6$ ) and $0.2 \%$ bovine serum albumin (BSA), and then treated overnight with undiluted MAbs JIM5 or JIM7. After washing, sections were incubated with $15 \mathrm{~nm}$ of colloidal gold-Ig complex (goat anti-rat; Bio Cell, Cardiff, U.K.) containing 1\% BSA (diluted 1:20 in TBS) for $1 \mathrm{~h}$. MAb for $\beta-1,3$ glucans was diluted $1: 100$ and secondary antibody (goat anti-mouse; Bio Cell, Cardiff, U.K.) was diluted 1:20 in TBS. The specificity of immunolabeling reactions was determined by treating grids with MAbs JIM5 or JIM7 preabsorbed with $1 \mathrm{mg} \cdot \mathrm{ml}^{-1}$ solutions of pectin or Na-polygalacturonate (Sigma Chimica, Milan, Italy) $12 \mathrm{~h}$ before the incubation at $4^{\circ} \mathrm{C}$ (Moore and Staehelin 1988). The MAb for $\beta-1,3$ glucans was preincubated with $100 \mu \mathrm{g} \cdot \mathrm{ml}^{-1}$ laminarin (Sigma Chimica, Milan, Italy) for $72 \mathrm{~h}$ at $4^{\circ} \mathrm{C}$. Other control sections were run, replacing the primary antibody with buffer. Thin sections were post-stained with uranyl acetate and lead citrate before observation with a Philips CM 10 transmission electron microscope (Philips, Eindhoven, The Netherlands).

Immunofluorescence was performed on semithin sections. They were washed with $50 \mathrm{mM}$ PBS, $\mathrm{pH} 7.2$, saturated $1 \mathrm{~h}$ with $1 \%(\mathrm{wt} / \mathrm{vol}) \mathrm{BSA}$ in the same buffer, treated with the MAbs (diluted 1:200) overnight at $4^{\circ} \mathrm{C}$, and then washed with PBS. The secondary antibodies were FITC-conjugated (Sigma) and were used at the recommended dilution (1:60). Sections were then observed under a Nikon Optiphot-2 microscope equipped with a Bio-Rad View Scan DVC-250 confocal system, under an excitation light of $488 \mathrm{~nm}$.

\section{ACKNOWLEDGMENTS}

IGER is grant aided by BBSRC and part of this work was done under BBSRC PMB phase II initiative. Research at The Sainsbury Laboratory is funded by the Gatsby Charitable Trust. Research at the Dipartimento di Biologia Vegetale dell'Università di Torino and CSMT-CNR is funded by MURST $60 \%$ and CNR grants. L. S. was supported by the SJVF Whole Plant Physiology Initiative.

\section{LITERATURE CITED}

Albrecht, C., Geurts, R., and Bisseling, T. 1999. Legume nodulation and mycorrhizae formation; two extremes in host specificity meet. EMBO J. 18:281-288.

Albrecht, C., Geurts, R., Lapeyrie, F., and Bisseling, T. 1998. Endomycorrhizae and rhizobial Nod factors both require SYM8 to induce the expression of the early nodulin genes PsENOD5 and PsENOD12A. Plant J. 15:605-614.

Balaji, B., Ba, A. M., Larue, T. A., Tepfer, D., and Piche, Y. 1994. Pisum sativum mutants insensitive to nodulation are also insensitive to invasion in-vitro by the mycorrhizal fungus, Gigaspora margarita. Plant Sci. 102:195-203.

Balestrini, R., Hahn, M., Faccio, A., Mendgen, K., and Bonfante, P. 
1996. Differential localization of carbohydrate epitopes in plant cell walls in the presence and absence of arbuscular mycorrhizal fungi. Plant Physiol. 111:203-213.

Barker, S. J., Stummer, B., Gao, L., Dispain, I., O'Connor, P. J., and Smith, S. E. 1998a. A mutant in Lycopersicon esculentum Mill. with highly reduced VA mycorrhizal colonization: Isolation and preliminary characterisation. Plant J. 15:791-797.

Barker, S. J., Tagu, D., and Delp, G. 1998b. Regulation of root and fungal morphogenesis in mycorrhizal symbiosis. Plant Physiol. 116: 1201-1207.

Boivin, C., Camut, S., Malpica, C. A., Truchet, G., and Rosenberg, C. 1990. Rhizobium meliloti genes encoding catabolism of trigonelline are induced under symbiotic conditions. Plant Cell 2:1157-1170.

Bonfante, P. At the interface between mycorrhizal fungi and plants: The structural organization of cell wall, plasma membrane and cytoskeleton. In: The Mycota IX. B. Hoch, ed. Springer-Verlag, Berlin. In press.

Bonfante, P., and Perotto, S. 1995. Tansley Review No. 82. Strategies of arbuscular mycorrhizal fungi when infecting host plants. New Phytol. 130:3-21.

Borisov, A. Y., Rozov, S. M., Tsyganov, V. E., Kulikova, O. A., Kolycheva, A. N., Yakobi, L. M., Ovtsyna, A. O., and Tikhonovich, I. A. 1994. Identification of symbiotic genes in pea (Pisum sativum L.) by means of experimental mutagenesis. Genetika 30:1484-1494.

Bradbury, S. M., Peterson, R. L., and Bowley, S. R. 1993. Further evidence for a correlation between nodulation genotypes in alfalfa (Medicago sativa L.) and mycorrhiza formation. New Phytol. 124: 665-673.

Dangl, J. L., Dietrich, R. A., and Richberg, M. A. 1996. Death don't have no mercy: Cell death programs in plant-microbe interactions. Plant Cell 8:1793-1807.

Duc, G., Trouvelot, A., Gianinazzi-Pearson, V., and Gianinazzi, S. 1989. First report of non-mycorrhizal plant mutants (Myc-) obtained in pea (Pisum sativum L.) and fava bean (Vicia faba L.). Plant Sci. 60:215222.

Garriock, M. L., Peterson, R. L., and Ackerley, C. A. 1989. Early stages in colonization of Allium porrum (leek) roots by the vesicular-arbuscular mycorrhizal fungus, Glomus versiforme. New Phytol. 112:85-92.

Gianinazzi-Pearson, V. 1996. Plant cell responses to arbuscular mycorrhizal fungi: Getting to the roots of the symbiosis. Plant Cell 8: 1871-1883.

Giovannetti, M., Avio, L., Sbrana, C., and Citernesi, A. S. 1993. Factors affecting appressorium development in the vesicular-arbuscular mycorrhizal fungus Glomus mosseae (Nicol. \& Gerd.) Gerd. \& Trappe. New Phytol. 123:115-122.

Giovannetti, M., Sbrana, C., Citernesi, A. S., and Avio, L. 1996. Analysis of factors involved in fungal recognition responses to host-derived signals by arbuscular mycorrhizal fungi. New Phytol. 133:65-71.

Gollotte, A., Gianinazzi-Pearson, V., Giovannetti, M., Sbrana, C., Avio, L., and Gianinazzi, S. 1993. Cellular localization and cytochemical probing of resistance reactions to arbuscular mycorrhizal fungi in a 'locus a' myc- mutant of Pisum sativum L. Planta 191:112-122.

Grippiolo, R., and Bonfante, P. 1984. Sporopollenin and melanin-like pigments in the wall of a Glomus spore. Giorn. Bot. Ital. 118:88-90.

Handberg, K., and Stougaard, J. 1992. Lotus japonicus, an autogamous, diploid legume species for classical and molecular genetics. Plant J. 2: 487-496.

Harrison, M. J. 1999a. Biotrophic interfaces and nutrient transport in plant/fungal symbioses. J. Exp. Bot. 50(Special Issue):1013-1022.

Harrison, M. J. 1999b. Molecular and cellular aspects of the arbuscular mycorrhizal symbiosis. Annu. Rev. Plant Physiol. Plant Mol. Biol. 50: 361-389.

Heath, M. C. 1997. Signalling between pathogenic rust fungi and resistant or susceptible host plants. Ann. Bot. 80:713-720.

Heidstra, R., Geurts, R., Franssen, H., Spaink, H. P., van Kammen, A., and Bisseling, T. 1994. Root hair deformation activity of nodulation factors and their fate on Vicia sativa. Plant Physiol. 105:787-797.

Hirsch, A. M., and Kapulnik, Y. 1998. Signal transduction pathways in mycorrhizal associations: comparisons with the Rhizobium-legume symbiosis. Fungal Genet. Biol. 23:205-212.

Imaizumi-Anraku, H., Kawaguchi, M., Koiwa, H., Akao, S., and Syono, K. 1997. Two ineffective-nodulating mutants of Lotus japonicus. Different phenotypes caused by the blockage of endocytotic bacterial re- lease and nodule maturation. Plant Cell Physiol. 38:871-881.

Jones, J. D. G. 1994. Paranoid plants have their genes examined. Curr. Biol. 4:749-751.

Knox, J. P., Linstead, P. J., Cooper, C., and Roberts, K. 1990. Pectin esterification is spatially regulated both within cell walls and between developing tissues of root apices. Planta 181:512-521.

Markwei, C. M., and LaRue, T. A. 1992. Phenotypic characterization of Sym8 and Sym 9, two genes conditioning non-nodulation in Pisum sativum sparkle. Can. J. Microbiol. 38:548-554.

Moore, P. J., and Staehelin, L. A. 1988. Immunogold localization of the cell-wall matrix polysaccharides rhamnogalacturonan I and xyloglucan during cell expansion and cytokinesis in Trifolium pratense L.; Implication for secretory pathways. Planta 174:433-445.

Moore, P. J., Swords, K. M. M., Lynch, M. A., and Staehelin, L. A 1991. Spatial organization of the assembly pathways of glycoproteins and complex polysaccharides in the Golgi apparatus of plants. J. Cell Biol. 112:589-602.

Nagahashi, G., and Douds, D. D., Jr. 1997. Appressorium formation by AM fungi on isolated cell walls of carrot roots. New Phytol. 136:299304.

Parniske, M. 2000. Intracellular accommodation of microbes by plants: A common developmental program for symbiosis and disease? Curr. Opin. Plant Biol. 3:320-328.

Perotto, S., Brewin, N. J., and Bonfante, P. 1994. Colonization of pea roots by the mycorrhizal fungus Glomus versiforme and by Rhizobium bacteria: Immunological comparison using monoclonal antibodies as probes for plant cell surface components. Mol. Plant-Microbe Interact. 7:91-98.

Postma, J. G., Jacobsen, E., and Feenstra, W. J. 1988. 3 Pea mutants with an altered nodulation studied by genetic-analysis and grafting. J. Plant Physiol. 132:424-430.

Remy, W., Taylor, T. N., Hass, H., and Kerp, H. 1994. Four hundredmillion-year-old vesicular arbuscular mycorrhizae. Proc. Natl. Acad. Sci. U.S.A. 91:11841-11843.

Sagan, M., Morandi, D., Tarenghi, E., and Duc, G. 1995. Selection of nodulation and mycorrhizal mutants in the model plant Medicago truncatula (Gaerth.) after $\gamma$-ray mutagenesis. Plant Sci. 111:63-71.

Schauser, L., Handberg, K., Sandal, N., Stiller, J., Thykjaer, T., Pajuelo, E., Nielsen, A., and Stougaard, J. 1998. Symbiotic mutants deficient in nodule establishment identified after T-DNA transformation of $L o$ tus japonicus. Mol. Gen. Genet. 259:414-423.

Schauser, L., Roussis, A., Stiller, J., and Stougaard, J. 1999. A plant regulator controlling development of symbiotic nodules. Nature 402:191-195.

Schneider, A., Walker, S., Poyser, S., Sagan, M., Ellis, T., and Downie, J. 1999. Genetic mapping and functional analysis of a nodulationdefective mutant (sym19) of pea (Pisum sativum L.). Mol. Gen. Genet. 262:1-11.

Shirtliffe, S. J., and Vessey, K. J. 1996. A nodulation (Nod+ Fix+) mutant of Phaseolus vulgaris L. has nodule-like structures lacking peripheral vascular bundles (Pvb-) and is resistant to mycorrhizal infection (Myc-). Plant Sci. 118:209-220.

Smith, F. A., and Smith, S. E. 1997. Tansley Review No. 96. Structural diversity in (vesicular)-arbuscular mycorrhizal symbioses. New Phytol. $137: 373-388$.

Stougaard, J., Szczyglowski, K., de Bruijn, F. J., and Parniske, M. 1999. Genetic nomenclature guidelines for the model legume Lotus japonicus. Trends Plant Sci. 4:300-301.

Szczyglowski, K., Shaw, R. S., Wopereis, J., Copeland, S., Hamburger, D., Kasiborski, B., Dazzo, F. B., and de Bruijn, F. J. 1998. Nodule organogenesis and symbiotic mutants of the model legume Lotus japonicus. Mol. Plant-Microbe Interact. 11:684-697.

Trouvelot, A., Kough, J. L., and Gianinazzi-Pearson, V. 1986. Mesure du taux de mycorhization VA d'un système radiculaire. Recherche de méthodes d'estimation ayant une signification functionnelle. Pages 217-221 in: Les mycorrhizes: Physiologie et génétique. INRA, Paris.

Van der Heijden, M. G. A., Klironomos, J. N., Ursic, M., Moutoglis, P., Streitwolf-Engel, R., Boller, T., Wiemken, A., and Sanders, I. R. 1998. Mycorrhizal fungal diversity determines plant biodiversity, ecosystem variability and productivity. Nature 396:69-72.

Wegel, E., Schauser, L., Sandal, N., Stougaard, J., and Parniske, M. 1998. Mycorrhiza mutants of Lotus japonicus define genetically independent steps during symbiotic infection. Mol. Plant-Microbe Interact. 11:933-936. 